\title{
AKTIVITAS ANTI-INFLAMASI IN VITRO EKSTRAK ETANOL DAUN Vernonia amygdalina DELILE DENGAN PENGUJIAN STABILISASI MEMBRAN
}

\author{
Muhammad Khairul Nuryanto ${ }^{1 *}$, Swandari Paramita ${ }^{1}$, Abdillah Iskandar $^{2}$, \\ Sjarif Ismail ${ }^{3}$, Andre Kusuma Ruslim ${ }^{4}$ \\ ${ }^{1}$ Laboratorium Ilmu Kedokteran Komunitas, Fakultas Kedokteran, Universitas Mulawarman \\ ${ }^{2}$ Laboratorium Mikrobiologi, Fakultas Kedokteran, Universitas Mulawarman \\ ${ }^{3}$ Laboratorium Farmakologi, Fakultas Kedokteran, Universitas Mulawarman \\ ${ }^{4}$ Program Studi Pendidikan Dokter Gigi, Fakultas Kedokteran, Universitas Mulawarman \\ *Corresponding author email: khairul.nuryanto@gmail.com
}

\begin{abstract}
Inflammation is a normal process in the human body as a response to injury from the healing process. Meanwhile, chronic inflammation will cause new health problems to patients. Anti-inflammatory agents generally used for those conditions, have several side effects to patients. The objective of this research was to find alternative anti-inflammatory agents, especially from natural sources. Vernonia amygdalina Delile knew locally as "Daun Bismillah" belong to family Apiaceae is one of those potential natural sources for alternative anti-inflammatory agents. This plant is known as traditional medicine and used as material in this research. The experimental method of in vitro anti-inflammatory measurement using membrane stabilization activity for ethanol extracts of $V$. amygdalina leaves. The results showed that significant differences of EC50 $(p<0.05)$ were achieved between indomethacin as the positive control with $V$. amygdalina leaves extracts for concentration 1\% and 10\%. EC50 of leaves ethanol extract of V. amygdalina showed the potential antiinflammatory activities. It could be concluded that $V$. amygdalina leaves ethanol extracts to have antiinflammatory activities, which could be further developed as a new natural source of the anti-inflammatory agents.
\end{abstract}

Keywords: Anti-inflammatory, in vitro, Vernonia amygdalina, membrane stabilization

\begin{abstract}
ABSTRAK
Peradangan adalah proses normal sebagai respon terhadap jejas, yang berperan penting dalam proses penyembuhan. Namun proses peradangan yang kronis akan menimbulkan masalah bagi pasien. Untuk mengatasinya digunakan agen anti-inflamasi yang memiliki efek samping terkait penggunaannya. Hal ini membuat pentingnya pencarian alternatif obat anti-inflamasi, terutama yang berasal dari bahan alam. Vernonia amygdalina Delile dikenal masyarakat lokal dengan nama "Daun Bismillah" merupakan salah satu sumber bahan alam yang potensial sebagai agen anti-inflamasi. Tumbuhan ini digunakan sebagai obat tradisional dan digunakan sebagai material dalam penelitian ini. Metode pengukuran anti-inflamasi in vitro yang digunakan adalah pengukuran aktivitas stabilisasi membran dari ekstrak etanol daun V. amygdalina. Hasilnya menunjukkan perbedaan signifikan EC50 (p<0,05) antara indometasin sebagai kontrol positif, dengan ekstrak etanol daun $V$. amygdalina konsentrasi $1 \%$ dan $10 \%$. Hasil EC50 V. amygdalina menunjukkan aktivitas anti-inflamasi yang potensial. Dapat disimpulkan bahwa ekstrak etanol daun $V$. amygdalina memiliki aktivitas anti-inflamasi, yang dapat dikembangkan lebih lanjut sebagai sumber bahan alam baru untuk agen anti-inflamasi.
\end{abstract}

Kata kunci: Anti-inflamasi, in vitro, Vernonia amygdalina, pengujian stabilisasi membran.

Submitted on: 7 November2017 Accepted on: 1 Desember 2017

DOI: https://org.doi/10.25026/jsk.v1i8.80

\section{PENDAHULUAN}

Inflamasi merupakan sebuah proses fisiologis dalam tubuh sebagai respon terhadap adanya jejas pada bagian tubuh, seperti pada kondisi kelelahan akibat kerja. Inflamasi akut dapat dipicu oleh berbagai rangsangan dan ditandai dengan respon cepat host pada lokasi infeksi atau 
jaringan trauma, yaitu pengantaran lekosit dan protein plasma seperti antibodi, menuju lokasi inflamasi. Inflamasi kronis dapat berlanjut setelah proses inflamasi akut, yang berlangsung selama beberapa minggu, bulan bahkan tahunan [1].

Selama proses inflamasi akut dan kronis, sejumlah mediator kimiawi akan dilepaskan. Sejumlah besar mediator inflamasi dilepaskan melalui jalur asam arakidonat, antara lain prostaglandin, sebagai hasil pemecahan asam arakidonat oleh enzim siklooksigenase. Meskipun proses ini merupakan proses fisiologis dalam tubuh, namun jika proses ini berlebihan, maka akan muncul dampak yang kurang baik bagi pasien. Untuk mengatasinya digunakan obat-obatan anti-inflamasi, dengan sejumlah efek samping terkait penggunaan obat tersebut. Beberapa efek samping yang menonjol dari penggunaan obat antiinflamasi adalah efek samping terhadap sistem gastrointestinal yang meningkatkan risiko terjadinya tukak lambung; serta sistem kardiovaskuler yang meningkatkan risiko terjadinya sumbatan pembuluh darah akibat bekuan darah. Hal ini yang membuat gencarnya upaya pencarian alternatif obat antiinflamasi, terutama yang berasal dari bahan alam [2].

Indonesia adalah negara yang terkenal akan keanekaragaman hayati termasuk kaya akan tumbuhan berkhasiat obat. Indonesia dikenal sebagai negara dengan keanekaragaman etnis dan budaya. Masing-masing etnis memiliki khasanah budaya yang berbeda. Setiap etnis memiliki kearifan lokal masyarakat, termasuk di dalamnya adalah pemanfaatan tumbuhan untuk pengobatan tradisional. Pengetahuan tentang penggunaan tumbuhan obat oleh etnis asli setempat sangat penting untuk pengembangan pengobatan secara tradisional dan pengembangan obat modern karena banyak ekstrak tumbuhan untuk obat modern ditemukan melalui pendekatan pengetahuan lokal. Pemanfaatan data tumbuhan obat hasil penelitian etnobotani merupakan salah satu cara yang efektif dalam menemukan bahan-bahan kimia baru yang berguna bagi pengobatan [3].

Salah satu tumbuhan obat yang diduga memiliki potensi aktivitas antiinflamasi adalah Vernonia amygdalina Delile. Tumbuhan yang berbentuk perdu ini termasuk dalam famili Compositae [4]. Tumbuhan ini disebut masyarakat lokal di Kalimantan dan Malaysia sebagai "Daun Bismillah". Selain itu juga dikenal dengan nama umum dalam Bahasa Indonesia sebagai "Daun Afrika" dan "Bitter Leaf" dalam Bahasa Inggris. Pengamatan awal terhadap penggunaan $V$. amygdalina adalah bahwa tumbuhan ini biasa dikonsumsi oleh simpanse liar yang terlihat sakit dan dalam beberapa waktu kemudian terlihat sehat dan beraktivitas normal kembali [5]. Penggunaan tradisional obat ini adalah untuk obat cacingan, anti malaria dan konstipasi [6]. Berdasarkan hal tersebut diatas maka penelitian ini bermaksud untuk melihat mekanisme aksi antiinflamasi ekstrak $V$. amygdalina dengan menggunakan uji stabilisasi membran.

\section{METODE PENELITIAN}

\section{Waktu dan Tempat}

Penelitian dilakukan pada bulan September 2017. Lokasi pengambilan sampel tumbuhan obat dilakukan di Kabupaten Kutai Kartanegara, Kalimantan Timur. Pengolahan sampel tumbuhan obat hingga proses uji stabilisasi membran dilakukan di Laboratorium Riset, Fakultas Kedokteran Universitas Mulawarman. 


\section{Pembuatan Ekstrak Tumbuhan Obat}

Simplisia yang telah dihaluskan lalu dimaserasi dengan pelarut etanol. Pada penelitian ini digunakan pelarut etanol absolut. Untuk pembuatan ekstrak, dimasukkan satu bagian serbuk kering simplisia ke dalam maserator (ditimbang botol maserasi sebelum dimasukkan simplisia dan ditimbang ulang setelah dimasukkan simplisia), ditambahkan 10 bagian pelarut (ukur volume sebelum dimasukkan). Selanjutnya direndam selama 6 jam sambil sesekali diaduk (menggunakan shaker orbital dengan kecepatan $20 \mathrm{rpm}$ selama 10 menit) pada suhu kamar, kemudian didiamkan selama 18 jam. Maserat dipisahkan dengan cara filtrasi dengan menggunakan kertas saring Whatman. Proses penyarian diulangi dua kali dengan jenis dan jumlah pelarut yang sama. Semua maserat dikumpulkan, kemudian diuapkan dengan vakum rotavapor suhu $50^{\circ} \mathrm{C}$ hingga diperoleh ekstrak kental. Ekstrak pekat yang didapat kemudian dikeringkan lebih lanjut dengan dimasukkan dalam desikator yang berisi silika gel biru dalam oven suhu $50^{\circ} \mathrm{C}$. Setelah didapatkan ekstrak kering, dihitung rendemen yang diperoleh, yaitu persentase bobot (b/b) antara rendemen dengan bobot serbuk simplisia yang digunakan dengan cara penimbangan. Ekstrak kering disimpan dalam kulkas $-20^{\circ} \mathrm{C}$ sebelum dilakukan penelitian lebih lanjut [7].

\section{Uji Stabilitas Membran}

Sampel darah subyek segar diambil dengan penambahan antikoagulan. Sampel darah disentrifugasi dalam suhu ruangan. Supernatan (plasma dan leukosit) dengan hati-hati dikeluarkan, sementara sel darah merah dicuci dengan normal salin. Proses pencucian dan sentrifugasi diulang hingga 5 kali hingga supernatan jernih. Kemudian sediaan eritrosit disiapkan untuk uji aktivitas stabilisasi membran. Uji aktivitas stabilisasi membran menggunakan suspensi eritrosit dengan Indometasin sebagai kontrol positif. Campuran terdiri dari larutan hiposalin natrium klorida, buffer natrium fosfat, suspensi eritrosit, bahan uji (standar kontrol positif dan ekstrak tumbuhan obat) dan campuran akhir ditambahkan dengan normal salin. Bahan uji tidak ditambahkan pada kontrol darah, sementara pada kontrol obat tidak ditambahkan suspensi eritrosit. Campuran larutan diinkubasi dalam water bath, diikuti dengan sentrifugasi dalam suhu ruang. Absorban hemoglobin yang dikeluarkan dibaca pada panjang gelombang $560 \mathrm{~nm}$. Persentase stabilitas membran dihitung dengan rumus sebagai berikut, dengan kontrol darah menunjukkan lisis $100 \%$ atau stabilitas $0 \%=100-($ absorban perlakuan absorban kontrol obat) $\times 100$ [8][9] .

\section{Analisis Data}

Aktivitas stabilisasi membran ditabulasikan dalam bentuk mean $\pm \mathrm{SD}$, kemudian dihitung nilai $\mathrm{EC}_{50}$. Perbedaan terhadap kontrol dilihat dengan uji t dan dikatakan signifikan jika $\mathrm{p}<0,05$.

\section{HASIL}

Hasil absorbansi stabilisasi membran ekstrak etanol $V$. amygdalina untuk konsentrasi $1 \%$ yang terendah pada dosis $100 \mathrm{mg} / \mathrm{ml}$ sebesar $0,383 \pm 0,001$ ditunjukkan pada Tabel 1. Hasil absorbansi stabilisasi membran ekstrak etanol $V$. amygdalina pada konsentrasi $10 \%$ untuk konsentrasi $10 \%$ yang terendah pada dosis $100 \mathrm{mg} / \mathrm{ml}$ sebesar 0,190 $\pm 0,010$ ditunjukkan pada Tabel 2 . Hasil absorbansi stabilisasi membran Indometasin sebagai kontrol positif yang terendah pada dosis $100 \mathrm{mg} / \mathrm{ml}$ sebesar 0,079 $\pm 0,009$ ditunjukkan pada Tabel 3 . Nilai EC $_{50}$ aktivitas stabilisasi membran $V$. amygdalina pada konsentrasi $1 \%$ 
adalah sebesar $131,81 \pm 2,95 \mathrm{ug} / \mathrm{mL}$ dan pada konsentrasi $10 \%$ adalah sebesar $62,54 \pm 2,05 \mathrm{ug} / \mathrm{mL}$ jika dibandingkan dengan indometasin $26,39 \pm 2,91 \mathrm{ug} / \mathrm{mL}$, seperti yang ditunjukkan pada Tabel 4.

Tabel 1. Hasil absorbansi stabilisasi membran ekstrak V. amygdalina konsentrasi 1\%

\begin{tabular}{cccccc}
\hline $\begin{array}{c}\text { Dosis } \\
(\mathbf{m g} / \mathbf{m l})\end{array}$ & $\begin{array}{c}\text { Absorbansi } \\
\text { Sampel I }\end{array}$ & $\begin{array}{c}\text { Absorbansi } \\
\text { Sampel II }\end{array}$ & $\begin{array}{c}\text { Absorbansi } \\
\text { Sampel III }\end{array}$ & $\begin{array}{c}\text { Rerata } \\
\text { Absorbansi }\end{array}$ & $\begin{array}{c}\text { Standar Deviasi } \\
\text { Absorbansi }\end{array}$ \\
\hline $\mathbf{2 , 5}$ & 0,720 & 0,716 & 0,716 & 0,717 & 0,002 \\
$\mathbf{5}$ & 0,699 & 0,722 & 0,716 & 0,712 & 0,012 \\
$\mathbf{1 2 , 5}$ & 0,697 & 0,693 & 0,690 & 0,693 & 0,004 \\
$\mathbf{2 5}$ & 0,665 & 0,668 & 0,673 & 0,669 & 0,004 \\
$\mathbf{5 0}$ & 0,578 & 0,547 & 0,569 & 0,565 & 0,016 \\
$\mathbf{1 0 0}$ & 0,384 & 0,383 & 0,382 & 0,383 & 0,001 \\
\hline
\end{tabular}

Tabel 2. Hasil absorbansi stabilisasi membran ekstrak V. amygdalina konsentrasi $10 \%$

\begin{tabular}{cccccc}
\hline $\begin{array}{c}\text { Dosis } \\
(\mathbf{m g} / \mathbf{m l})\end{array}$ & $\begin{array}{c}\text { Absorbansi } \\
\text { Sampel I }\end{array}$ & $\begin{array}{c}\text { Absorbansi } \\
\text { Sampel II }\end{array}$ & $\begin{array}{c}\text { Absorbansi } \\
\text { Sampel III }\end{array}$ & $\begin{array}{c}\text { Rerata } \\
\text { Absorbansi }\end{array}$ & $\begin{array}{c}\text { Standar Deviasi } \\
\text { Absorbansi }\end{array}$ \\
\hline $\mathbf{2 , 5}$ & 0,640 & 0,610 & 0,610 & 0,619 & 0,020 \\
$\mathbf{5}$ & 0,577 & 0,571 & 0,570 & 0,573 & 0,004 \\
$\mathbf{1 2 , 5}$ & 0,405 & 0,565 & 0,551 & 0,507 & 0,089 \\
$\mathbf{2 5}$ & 0,340 & 0,332 & 0,327 & 0,333 & 0,007 \\
$\mathbf{5 0}$ & 0,204 & 0,197 & 0,276 & 0,226 & 0,044 \\
$\mathbf{1 0 0}$ & 0,200 & 0,190 & 0,181 & 0,190 & 0,010 \\
\hline
\end{tabular}

Tabel 3. Hasil absorbansi stabilisasi membran Indometasin (kontrol positif)

\begin{tabular}{cccccc}
\hline $\begin{array}{c}\text { Dosis } \\
(\mathbf{m g} / \mathbf{m l})\end{array}$ & $\begin{array}{c}\text { Absorbansi } \\
\text { Sampel I }\end{array}$ & $\begin{array}{c}\text { Absorbansi } \\
\text { Sampel II }\end{array}$ & $\begin{array}{c}\text { Absorbansi } \\
\text { Sampel III }\end{array}$ & $\begin{array}{c}\text { Rerata } \\
\text { Absorbansi }\end{array}$ & $\begin{array}{c}\text { Standar Deviasi } \\
\text { Absorbansi }\end{array}$ \\
\hline $\mathbf{2 , 5}$ & 0.539 & 0.523 & 0.527 & 0.530 & 0.008 \\
$\mathbf{5}$ & 0.457 & 0.450 & 0.392 & 0.433 & 0.036 \\
$\mathbf{1 2 , 5}$ & 0.255 & 0.298 & 0.250 & 0.268 & 0.026 \\
$\mathbf{2 5}$ & 0.129 & 0.117 & 0.109 & 0.118 & 0.010 \\
$\mathbf{5 0}$ & 0.098 & 0.106 & 0.102 & 0.102 & 0.004 \\
$\mathbf{1 0 0}$ & 0.068 & 0.082 & 0.086 & 0.079 & 0.009 \\
\hline
\end{tabular}

Tabel 4. Perbedaan EC50 pada uji stabilisasi membran antara V. amygdalina $1 \%$ dan $10 \%$ dengan Indometasin sebagai kontrol positif

\begin{tabular}{cccccc}
\hline Sediaan & $\begin{array}{c}\text { EC50 } \\
\text { Sampel I }\end{array}$ & $\begin{array}{c}\text { EC }_{\mathbf{5 0}} \\
\text { Sampel II }\end{array}$ & $\begin{array}{c}\text { EC }_{\mathbf{5 0}} \\
\text { Sampel III }\end{array}$ & $\begin{array}{c}\text { Rerata } \\
\text { EC }_{\mathbf{5 0}}\end{array}$ & $\begin{array}{c}\text { Standar Deviasi } \\
\text { EC }_{\mathbf{5 0}}\end{array}$ \\
\hline V. amygdalina 1\% & 134,66 & 128,77 & 132,01 & 131,81 & 2,95 \\
V. amygdalina 10\% & 61,21 & 61,52 & 64,90 & 62,54 & 2,05 \\
Indometasin & 27,89 & 28,23 & 23,04 & 26,39 & 2,91 \\
\hline
\end{tabular}

Keterangan: ANOVA p $<0,05$ 


\section{PEMBAHASAN}

Semakin kecil konsentrasi $\mathrm{EC}_{50}$ maka semakin baik aktivitas antiinflamasi sebagai stabilisasi membran. Hasil penelitian menunjukkan bahwa indometasin sebagai kontrol positif memiliki aktivitas anti-inflamasi yang lebih baik daripada $V$. amygdalina pada aktivitas stabilisasi membran. Hal ini menunjukkan bahwa aktivitas stabilisasi membran merupakan mekanisme aksi yang mungkin untuk aktivitas antiinflamasi $V$. amygdalina.

Sinonim tumbuhan ini adalah Bracheilema paniculatum R.Br., Cacalia amygdalina Kuntze, Cheliusia abyssinica Sch.Bip.ex A.Rich., Decaneurum amygdalinum DC., Vernonia adenosticta Fenzl ex Walp., Vernonia eritreana Klatt, Vernonia giorgii De Wild., Vernonia randii S.Moore, Vernonia Benth., dan Vernonia weisseana Muschl [4]. Tumbuhan ini dapat tumbuh setinggi 2-5 $m$ di daerah tropis, memiliki batang yang keras dengan warna kehitaman, dan daun berbentuk lonjong berwarna hijau dengan bau yang khas dan rasa yang pahit. Komponen aktif $V$. amygdalina adalah saponin, alkaloid, terpen, steroid, kumarin, flavonoid, asam fenolik, lignan, xanton, antrakuinon, edotid dan seskuiterpen [10]. Aktivitas biologis $V$. amygdalina yang telah terbukti adalah efek antibakterial, antifungal, antiparasit, anticacing, antimalaria, antivirus, pestisida, antivirus, antimutagenik, antikanker, antifertilitas, antikoagulan, antioksidan, perlindungan liver, antidiabetes dan efek hipolipidemia [11].

Terdapat penelitian yang telah menunjukkan efek analgesik sentral dan perifer dari ekstrak $V$. amygdalina, melalui uji terhadap hewan coba dengan uji formalin dan uji writhing yang diinduksi dengan asam asetat [12]. Penelitian lain juga menemukan bahwa ekstrak $V$. amygdalina mampu menghambat edema tungkai tikus yang diinduksi oleh karaginan dan edema telinga tikus yang diinduksi oleh xylene. Penelitian tersebut menunjukkan bahwa ekstrak $V$. amygdalina memiliki aktivitas anti-inflamasi in vivo [13].

Sepanjang pengetahuan peneliti, ini adalah studi pertama yang meneliti tentang aktivitas anti-inflamasi dari ekstrak etanol daun $V$. amygdalina, dengan menggunakan uji stabilitas membran. Mekanisme kerja ekstrak etanol daun $V$. amygdalina sebagai agen anti-inflamasi diduga melalui kandungan flavonoid di dalamnya. Mekanisme yang penting untuk aktivitas anti-inflamasi adalah penghambatan enzim yang menghasilkan eikosanoid, termasuk fosfolipase A2, siklooksigenase dan lipoksigenase, sehingga menurunkan konsentrasi prostanoid dan leukotrien. Mekanisme yang lain termasuk penghambatan pelepasan histamin, fosfodiesterase, protein kinase dan aktivasi transkriptase [14].

\section{KESIMPULAN}

Hasil penelitian ini memperlihatkan aktivitas anti-inflamasi $V$. amygdalina melalui mekanisme stabilisasi membran. Perlu adanya penelitian lanjutan agar $V$. amygdalina dapat dikembangkan sebagai bahan anti-inflamasi baru berbasis tumbuhan obat.

\section{DAFTAR PUSTAKA}

[1]. Souza TRCL, Marques GS, Vieira ACQM, Freitas JCR, 2012. State of the Art of Antiinflammatory Drugs, Pharmacotherapy, Farid Badria (Ed), Rijeks, Croatia: Intech, 116-140.

[2]. Pountos I, Georgouli T, Howard B, Giannoudis PV, 2011. Nonsteroidal Antiinflammatory Drugs: Prostaglandins, Indications, and Side Effects, International Journal of Interferon, Cytokine and Mediator Research, 3, 19-27. 
[3]. Kementerian Kesehatan RI, 2016. Panduan Proposal dan Protokol Penelitian Lanjutan Riset Tumbuhan Obat dan Jamu, Badan Penelitian dan Pengembangan Kesehatan, Balai Besar Litbang Tanaman Obat dan Obat Tradisional, Kementerian Kesehatan RI, Tawangmangu.

[4]. The Plant List, 2013. Version 1.1. http://www.theplantlist.org.

[5]. Ijeh II, Ejike CECC, 2011. Current perspectives on the medicinal potentials of Vernonia amygdalina Del, Journal of Medicinal Plants Research, 5(7), 10511061.

[6]. Zakaria Y, Azlan NZ, Hassan NFN, Muhammad H, 2016. Phytochemicals and acute oral toxicity studies of the aqueous extract of Vernonia amygdalina from state of Malaysia, Journal of Medicinal Plants Studies, 4(3), 1-5.

[7]. Departemen Kesehatan RI, 2008. Farmakope Herbal Indonesia, Edisi Pertama, Departemen Kesehatan RI, Jakarta.

[8]. Oyedapo OO, Akinpelu BA, Akinwunmi KF, Adeyinka MO, Sipeolu FO, 2010. Red blood cell membrane stabilizing potentials of extracts of Lantana camara and its fractions, International Journal of Plant Physiology and Biochemistry, 2(4), 46-51.

[9]. Omale J, Okafor PN, 2008. Comparative antioxidant capacity, membrane stabilization, polyphenol composition and cytotoxicity of the leaf and stem of Cissus multistriata, African Journal of Biotechnology, 7(17), 3129-3133.
[10]. Farombi EO, Owoeye O, 2011. Antioxidative and chemopreventive properties of Vernonia amygdalina and Garcinia biflavanoid. International Journal of Environmental Research and Public Health, 8, 2533-2555.

[11]. Yeap SK, Ho WY, Beh BK, Liang WS, Ky H, Yousr AHN, Alitheen NB, 2010. Vernonia amygdalina, an ethnoveterinary and ethnomedical used green vegetable with multiple bio-activities, Journal of Medicinal Plant Research, 4(25), 27872812.

[12]. Njan AA, Adzu B, Agaba AG, Byarugaba D, Díaz-Llera S, Bangsberg DR, 2008. The Analgesic and Antiplasmodial Activities and Toxicology of Vernonia amygdalina, Journal of Medicinal Food, 11(3), 574-581.

[13]. Iroanya O, Okpuzor J, Mbagwu H, 2010. Anti-nociceptive and anti- phlogistic actions of a polyherbal decoction, International Journal of Pharmacology, 6, 31-36.

[14]. Rathee P, Chaudhary H, Rathee S, Rathee D, Kumar V, Kohli K, 2009. Mechanism of Action of Flavonoids as Anti-inflammatory Agents: A Review. Inflammation \& Allergy - Drug Targets, 8, 229-235. 